\title{
Inheritance of Flower Colour of Underutilized Tuberous Legume Crop Yam Bean (Pachyrhizus erosus L. Urban)
}

\author{
Kalidas Pati*, V. B. S. Chauhan, V. V. Bansode and M. Nedunchezhiyan \\ Regional Centre, ICAR-Central Tuber Crops Research Institute, \\ Bhubaneswar, 751019, Odisha, India \\ *Corresponding author
}

\section{A B S T R A C T}

\begin{tabular}{l} 
Ke y w o r d s \\
Yam bean, \\
Underutilized crop, \\
$\begin{array}{l}\text { Flower colour, } \\
\text { Inheritance }\end{array}$ \\
\hline Article Info \\
\hline $\begin{array}{l}\text { Accepted: } \\
\text { 05 April } 2020 \\
\text { Available Online: } \\
\text { 10 May 2020 }\end{array}$ \\
\hline
\end{tabular}

The inheritance pattern of flower colour in underutilized tuberous legume crop yam bean was studies by utilizing a white flower colour line (YBWF1) and two purple flower colour lines (RM-1 and L No-3). The $F_{1}$ and $F_{2}$ population along with parental lines were evaluated to study the inheritance pattern of the flower colour. All the $F_{1}$ hybrids showed purple colour in both the crosses and in the $F_{2}$ segregation generation, the observed distribution of the flower colour fitted the expected Mendalian ratio of 3 (Purple flower colour):1 (white flower colour). The segregation of flower colour suggested monogenic dominant control of purple flower colour in yam bean using white flower colour genotype YBWF-1. This is the first report of flower colour inheritance pattern in yam bean.

\section{Introduction}

Yam bean (Pachyrhizus erosus L.Urban) is a tuberous legume crop commonly known as Mishrikand, Sank alu or Sankeshalu in India, primarily grown for its tuberous roots. Now a days, it is gaining importance due to its high productivity, nutritional value and wider adaptability. Yam bean tuber rich in protein (0.72 g) (USDA, 2016) and teste resemble to water chest nut. In India, it is commonly grown in Bihar, Bengal, Odisha, eastern Uttar Pradesh and North-Eastern part of India. The chromosome number of $P$. erosus is $2 \mathrm{n}=2 \mathrm{x}=22$ (Santayana et al., 2014) and the genome size is estimated to be range from 572 to $597 \mathrm{Mbp}$ (Pati et al., 2019), Yam bean produces bisexual flower and self-pollinating nature. The species is characterized by the lack of hairs on the petals and inflorescence axis of complex racemes arising from the axil of the leaf (Sørensen, 1996). The common flower colour in yam bean is purple, but some white flower lines also available in the species. The flowering begins 58-68 days after sowing, and lasted 92-103 days. The 
stigma was found to become receptive at 12 hours before and to last for 18 hours after opening of the flower. The anthers generally dehisced 8-12 hours before opening of the flower (Prasad and Prakash, 1973). Flower colour was less influenced by environmental factors, hence, it can be used as a marker for species or varietal identification. Morphological markers are visually characterized phenotypic traits like flower colour and in terms of ornamental value the appealing of flower colour are useful for plant breeders (Golkar et al., 2010). Best of our knowledge no work has been carried out for the flower colour inheritance in yam bean. Therefore, the objective of this study was to identify the inheritance pattern and gene that control flower colour in yam bean.

\section{Materials and Methods}

This experiment was conducted at research farm of ICAR-Central Tuber Crops Research Institute, Regional Centre, Bhubaneswar, Odisha, CAR-Central Tuber Crops Research Institute, Regional Centre, Bhubaneswar, Odisha, India during 2016 -2018. Crosses were made between one white flower colour line (YBWF-1, Fig. 1) with two purple flower colour lines (RM-1 and L No-3, Fig. 1).The $\mathrm{F}_{1}$ (YBWF-1 $\times$ RM-1 and YBWF-1 $\times$ L No-3) progeny was selfed to obtain the $F_{2}$ generation. All pollinations were made by hand. Seeds of the parental lines, $F_{1}$ and $F_{2}$ were sown during end of August 2016, 2017 and 2018. Seeds were grown in rows with a spacing of $60 \mathrm{~cm}$ between rows and $30 \mathrm{~cm}$ between plants. All the recommended agronomic package of practices along with plant protection measures was followed to raise a successful crop of yam bean. Plants from each generation were evaluated for flower colour inheritance at flowering stage. Total number of plants were counted in each category and subjected to Chi-square $\left(\chi^{2}\right)$ test for their goodness of fit to monogenic inheritance ratios, as suggested by (Panse and Sukhatme, 1985).

\section{Results and Discussion}

The inheritance of flower colour was studied based on the Mendelian model, classifying purple flower and white flower plants. All the crosses (YBWF-1 $\times$ RM-1 and YBWF- $1 \times \mathrm{L}$ No-3) $F_{1}$ shows purple flower colour which indicated that purple flower colour is dominant over the white flower colour. The dominant trait of purple flower colour over white flower colour was further confirmed by $\mathrm{F}_{2}$.In the 'YBWF-1 $\times$ RM-1' cross 96 plants were producing purple flower and 24 plants producing white colour flower. The $\chi^{2}$ values indicated a good-fit to a $3: 1$ ratio $\left(\chi^{2}=1.60\right.$; $P=0.20$, Table 1$)$.

Table.1 Chi square $(\chi 2)$ analysis of $F_{2}$ population for studying inheritance pattern of flower colour in YBWF-1× RM-1

\begin{tabular}{|c|c|c|c|c|c|c|}
\hline \multirow[t]{2}{*}{ Generation } & \multirow{2}{*}{$\begin{array}{c}\text { Total } \\
\text { number of } \\
\text { plants }\end{array}$} & \multicolumn{2}{|c|}{ Observed ratio } & \multirow{2}{*}{$\begin{array}{l}\text { Expected } \\
\text { ratio }\end{array}$} & \multirow[t]{2}{*}{$\chi^{2}$-value } & \multirow[t]{2}{*}{ P- value } \\
\hline & & WF & $\mathrm{PF}$ & & & \\
\hline YBWF-1(White Flower) & 20 & 20 & - & - & - & - \\
\hline RM-1 (Purple flower) & 20 & - & 20 & - & - & - \\
\hline YBWF-1 x RM-1(F $\left.{ }_{1}\right)$ & 20 & - & 20 & - & - & - \\
\hline YBWF-1x RM-1 $\left(\mathrm{F}_{2}\right)$ & 120 & 24 & 96 & $3: 1$ & 1.60 & 0.20 \\
\hline
\end{tabular}


Table.2 Chi square $(\chi 2)$ analysis of $F_{2}$ population for studying inheritance pattern of flower colour in YBWF-1× L. No-3

\begin{tabular}{|l|c|c|c|c|c|c|}
\hline Generation & \multirow{2}{*}{$\begin{array}{c}\text { Total } \\
\text { number of } \\
\text { plants }\end{array}$} & Observed ratio & Expected & $\chi^{2}$-value & P-value \\
\cline { 1 - 5 } & & WF & PF & & \\
\hline YBWF-1(White Flower) & 20 & 20 & - & - & - & - \\
\hline L No-3 (Purple flower) & 20 & - & 20 & - & - & - \\
\hline YBWF-1 x L No-3 $\left(F_{1}\right)$ & 20 & - & 20 & - & - & - \\
\hline YBWF-1x L No-3 $\left(\mathrm{F}_{2}\right)$ & 120 & 26 & 94 & $3: 1$ & 0.71 & 0.39 \\
\hline
\end{tabular}

Fig.1 White flower colour line (RMWF-1) and Purple flower colour line (L No-3)

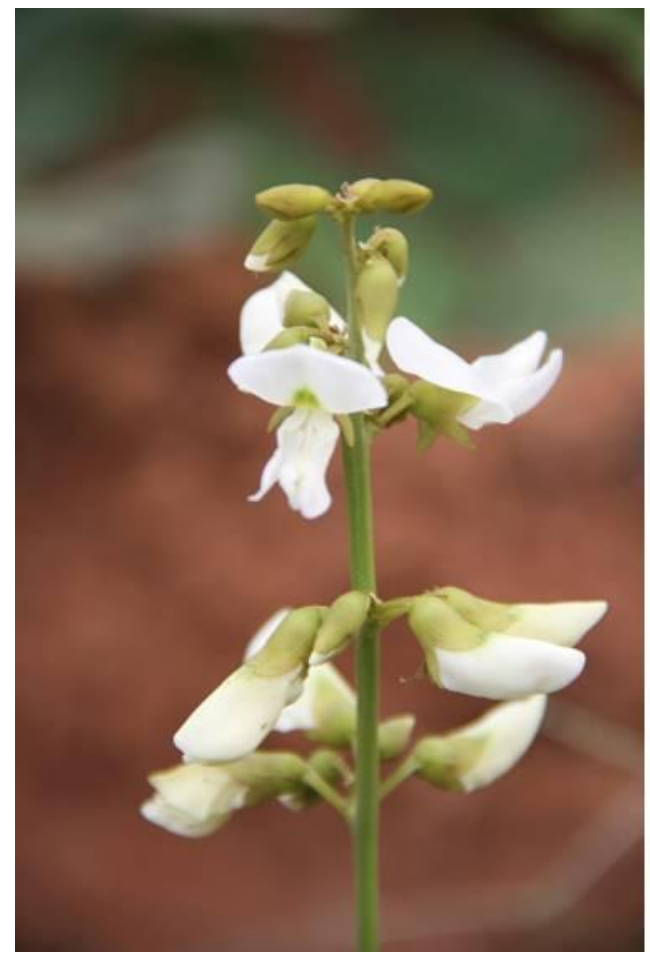

In the second cross 'YBWF-1 $\times$ L No-3', 94 plants were producing purple flower and 26 plants producing white colour flower. The $\chi^{2}$ values indicated a good-fit to a $3: 1$ ratio $\left(\chi^{2}=\right.$ $0.71 ; P=0.39$ Table 2$)$. The pattern of segregation in $F_{2}$ gave a goodness of fit to 3 Purple: 1 White (Table 1 and Table 2). On the basis of these results, it was confirmed that gene for purple colour was dominant over gene for white colour and this trait was

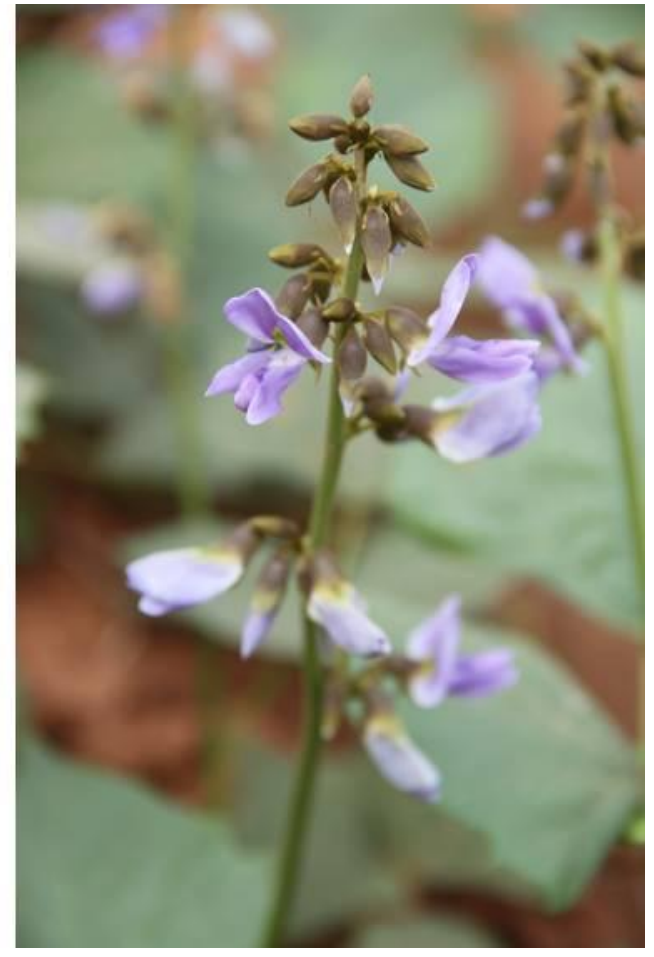

controlled by monogenic dominant gene its distribution fitted the expected mendelian ratio of 3 (Purple flower) : 1 (White flower). Jindla and Singh (1970), Hanchinal and RR (1978) reported dominant nature of violet flower colour over light violet colour in cowpea (Vigna sinesis L.). (Sangwan and Lodhi, 1998) reported purple flower colour was dominant over white flower colour in cowpea (Vigna unguiculata L. Walp.). 
(Panjehkeh et al., 2007) reported red flower line was dominant over white flower line in legume Swainsona formosa and in $\mathrm{F}_{2}$ population red flower line was resistant to Phytophthora cinnamomi. The association between flower colour and resistance may be due to anthocyanin pigment in the flower. Hence, the flower colour can be used as marker for this trait. Flowering is an important character and yam bean flower can be used for ornamental purpose. The findings of the present study could be utilized in ornamental breeding programme and inheritance pattern of pigment in yam bean flower.

\section{References}

Golkar, P., Arzani, A. and Rezaei, A. (2010). Inheritance of flower colour and spinelessness in safflower (Carthamus tinctorius L.). Journal of genetics 89(2): 259-262.

Hanchinal, R. and RR, H. (1978). Inheritance in Vigna.

Jindla, L. and Singh, K. (1970). Inheritance of flower colour, leaf shape and pod length in cowpea (Vigna sinensis L.). Indian Journal of Heredity 2(1): 45-49.

Panjehkeh, N., Backhouse, D. and Taji, A. (2007). Flower colour is associated with susceptibility to disease in the legume Swainsona formosa. Australasian Plant Pathology 36(4): 341-346.

Panse, V. and Sukhatme, P. (1985). Statistical methods for Agricultural workers (4th Edn.) ICAR. New Delhi 347.

Pati, K., Zhang, F. and Batley, J. (2019). First report of genome size and ploidy of the underutilized leguminous tuber crop Yam Bean (Pachyrhizus erosus and $P$. tuberosus) by flow cytometry. Plant Genetic Resources 17(5): 456-459.

Prasad, D. and Prakash, R. (1973). Floral biology of yam-bean, Pachyrhizus erosus (L.) Urb. Indian Journal of Agricultural Sciences 43(6): 531-535.

Sangwan, R.and Lodhi, G. (1998). Inheritance of flower and pod colour in cowpea (Vigna unguiculata L. Walp.). Euphytica 102(2): 191-193.

Santayana, M., Rossel, G., Núñez, J., Sørensen, M., Delêtre, M., Robles, R., Fernández, V., Grüneberg, W. J.and Heider, B. (2014). Molecular characterization of cultivated species of the genus Pachyrhizus Rich. ex DC. by AFLP markers: Calling for more data. Tropical Plant Biology 7(3-4): 121-132.

Sørensen, M. (1996). Yam Bean: Pachyrhizus DC.-Promoting the conservation and use of underutilized and neglected crops. 2. Bioversity International.

USDA (2016). National Nutrient Database for Standard Reference, Release 28. US Department of Agriculture, Agricultural Research Service, Nutrient Data Laboratory. http://www. ars. usda. gov/ba/bhnrc/ndl. Accessed 26.

\section{How to cite this article:}

Kalidas Pati, V. B. S. Chauhan, V. V. Bansode and Nedunchezhiyan, M. 2020. Inheritance of Flower Colour of Underutilized Tuberous Legume Crop Yam Bean (Pachyrhizus erosus L. Urban). Int.J.Curr.Microbiol.App.Sci. 9(05): 589-592. doi: https://doi.org/10.20546/ijcmas.2020.905.066 